\title{
EVALUATION OF THE POSSIBILITY TO USE SPORT AND RECREATION FACILITIES IN POZNAŃN
}

\author{
EWA KRUSZYŃSKA, ${ }^{1}$ L'UDMILA JANČOKOVÂ, ${ }^{2}$ \\ ELŻBIETA SIEŃKO-AWIERIANÓW ${ }^{3}$
}

\author{
${ }^{1}$ University of Szczecin \\ Faculty of Physical Culture and Health Promotion \\ Department of Individual Sports, Tourism and Recreation \\ e-mail: ewa.kruszynska@usz.edu.pl \\ ${ }^{2}$ Matej Bel University \\ Faculty of Arts \\ Department of Physical Education and Sports \\ Banská Bystrica, Slovak Republic \\ e-mail: ludmila.jancokova@umb.sk \\ ${ }^{3}$ University of Szczecin \\ Faculty of Physical Culture and Health Promotion \\ Department of Human Functional Anatomy and Biometry \\ e-mail: ela.sienko@wp.pl
}

\section{JEL CODES}

KEYWORDS

ABSTRACT
$\mathrm{I} 15, \mathrm{~L} 83, \mathrm{~L} 88$

sport and recreation infrastructure, sports and recreational services, surveys

The importance of sport, tourism and recreation in the development of cities and regions in the world is an already known and indisputable fact. A modern city possesses various public spaces where social activities take place, and where sport and recreation areas constitute a specific and attractive offer. Sport is an important field of activities carried out by authorities in Poznań, where spending on physical culture is among the highest in the country and is equal to the EU average in this respect. The aim of this article is to evaluate the possibility to use sport and recreation facilities in Poznań and sports-recreational activities offered there. In order to achieve this goal, questionnaire surveys were conducted among 39 service providers and 1,159 service recipients at selected sport-recreation facilities in Poznań. The analysis of service recipients' opinions, who were divided into amateur and professional athletes, has shown that both studied groups highly evaluated the level of equipment in sport and recreation facilities, the availability of services and the range of sports and recreational activities. The applied significance test of variances of tested variables between groups made it possible to distinguish significant differences in the distribution of analysed features and it reflects the diversity of opinions in the studied groups. These differences result from various expectations of professional and amateur athletes who use sport-recreation facilities regarding policy effectiveness performed by the City Government of Poznań. 


\section{Introduction}

The importance of sport and recreation in the development of cities and regions in the world is an already known and indisputable fact. At first, the role of sport and recreation in the activation of urban economy was discussed mainly in the United States (e.g. Baltimore, Boston), and later in the United Kingdom (e.g. Glasgow, Bradford, Edinburgh), France (e.g. Lyon), and Spain (e.g. Valencia). The European Union underlines the increasing importance of sport for the economy of the Community (Basińska-Zych, Bosiacki, 2011). For over a dozen years, the awareness of the significance of sport and recreation for the development of modern cities has been also increasingly growing in Poland.

The role of sport and recreation in cities may be treated as a factor that improves the quality of residents' life (social aspect), activates local economy (economic aspect), enriches the city image (psychological aspect), and restores urban space (cultural and spatial aspect).

“The Strategy of Sport Development in Poland until 2015" programme (the Ministry of Sport, 2007) identified necessary measures to achieve physical education and sport at the level comparable to the one in the developed countries of the European Union. This strategy distinguishes three priority activities: popularizing sport for all, increasing the level of sport results and developing sport and recreation infrastructure. The necessity to create such strategies results from rapid changes in the broadly understood environment as well as intensification of globalisation processes or competition between cities (for tourists, investments, funds).

A modern city possesses public spaces where social activities take place, and where sports and recreation areas constitute a specific and attractive offer. Although it is dedicated first and foremost to residents of a given city, it may also constitute an element expending tourist offer. Therefore, it enriches the urban environment with a function that often goes beyond its local impact, and thanks to the mass media, it is promoted even on a global scale. Sport, tourism and recreation are not only present in the spatial-functional structure of every city, although at different levels, but they are also exceptional and incomparable with other phenomena. Thanks to the variety of sports and recreation disciplines and purposes (for competitive and recreational sports), the sport-recreation infrastructure creates various spatial forms.

The importance of sport, tourism and recreation in the local development strategies is increasing every year. In order for local governments to achieve success, they need a long-term, consistently implemented strategy to support sport and recreation (Kogut-Jaworska, 2011).

The implementation of city development strategies is supported with the use of proper combination of marketing tools, especially promotional, which are supposed to gain clients interested in a product offered by a given place (Rogala, 2011). The effectiveness of promotional activities can be analysed at various levels, examining, among others, the opinion of service providers and recipients, who use sport and recreation facilities.

The aim of this article is to evaluate the possibility to use sport and recreation facilities in Poznań and sports-recreational activities offered there in the scale of the entire city and a district where service recipients live. 


\section{Research methods and techniques}

\section{Research material}

In order to achieve the objective presented in this article, a survey (a standardised interview method) was conducted. Nonprobability sampling of respondents (service providers and service recipients) was carried out in selected, year-round sport-recreation facilities. There are over $800 \mathrm{ob}-$ jects in the city of Poznań, which in the administrative nomenclature are referred to as sport and recreation facilities. This places Poznań at a favourable place among the members of the WHO Healthy Cities Network. The location of sport and recreation facilities in Poznań is proportional to the size of individual city districts: twice as many in Nowe Miasto, Stare Miasto and Grunwald as compared to the small districts of Jeżyce and Wilda. The managers of the sport and recreation facilities are the city authorities or natural persons. The availability of many facilities is limited due to subordination or the requirements of the clubs and sports organizations to which they belong. Whereas, the facilities that are fully open to public are playgrounds, ski slopes, equestrian centres, bowling alleys, tennis courts and indoor pools (data of the Poznań City Hall, 2012).

The above-mentioned data were the reason for choosing closed sport and recreation facilities, which were made available to residents of the city of Poznań, and allowed selection of respondents (service providers and recipients) in the sport and recreation facilities under study.

39 service providers (managers of a sports and recreation facility) and 1,159 service recipients (using the services of a given sports and recreation facility) took part in the survey, which was carried out at tennis courts (16 facilities), indoor pools (12 facilities), and fitness clubs (11 facilities) in Poznań (Table 1).

Table 1. The number of surveyed facilities and questionnaires carried out in individual facilities, by type

\begin{tabular}{lcc}
\hline \multicolumn{1}{c}{$\begin{array}{c}\text { Type of a surveyed sport } \\
\text { and recreation facility }\end{array}$} & $\begin{array}{c}\text { Number of the surveyed sport } \\
\text { and recreation facilities }\end{array}$ & Number of questionnaires \\
\hline Indoor tennis courts & 16 & 480 \\
Indoor pools & 12 & 360 \\
Fitness clubs & 11 & 319 \\
\hline
\end{tabular}

Source: own study.

\section{Research methods and techniques}

During project implementation, tests were carried out using primary data. The surveys (conducted using a standardised interview method) were chosen in order to collect primary data concerning the pace and directions of changes (trends) in sport and recreation facilities of the city of Poznań, with particular attention paid to distinguishment and hierarchization of factors determining this development. 
The questionnaires were directed to two groups of respondents. The first group included service providers (managers or owners) of sport and recreation facilities in the city of Poznań, while the other comprised service recipients (residents of the city of Poznań using the services offered in the examined sport and recreation facilities). In addition, service recipients were divided into a group of professional athletes, and people who have never been engaged in competitive sport.

Both groups of respondents could choose YES or NO answer in the questionnaire, and express their level of satisfaction/evaluation on a specified 1 to 10 point scale (1-unsatisfied, 10-very satisfied). The following research methods have been applied to perform the analysis of studied phenomena: descriptive statistics, histograms, test for equality of means (ANOVA) and tests for equality of variances.

\section{Research results}

The article evaluated the possibility to use sport and recreation facilities in Poznań as well as sports-recreational activities offered at them in the scale of the entire city and a district where service recipients live. Service recipients rated (from 1 to 10) the level of satisfaction with the availability of sports and recreational services in the scale of the entire city, and the possibility of using sport and recreation facilities in the place of residence together with the level of satisfaction with the availability of sport and recreation facilities on a scale (from 1 to 10) (Figures 1 and 2, Table 2).

The level of satisfaction with the availability of sport and recreation facilities in the city among both amateur and professional groups was similar. The minimal difference in the evaluation, presented in Figure 2, concerns the highest rates ( 9 and 10 points) given by professional athletes. In both groups, the values of kurtosis are relatively high, which indicates an occurrence of unusual values, in this case a high percentage of grades from 9 and 10 group. The analysis of skewness values, negative in both cases, leads to a similar conclusion, which implies high percentage of rates in the groups above the average.

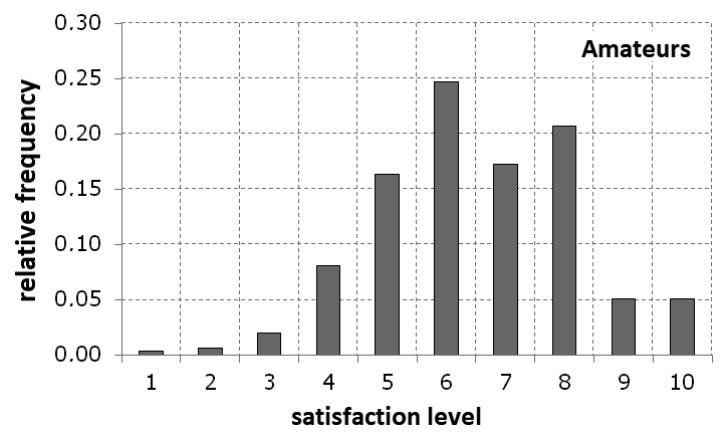

Figure 1. The availability of sport and recreation facilities in the city in the opinion of service recipients (amateurs) Source: own study. 


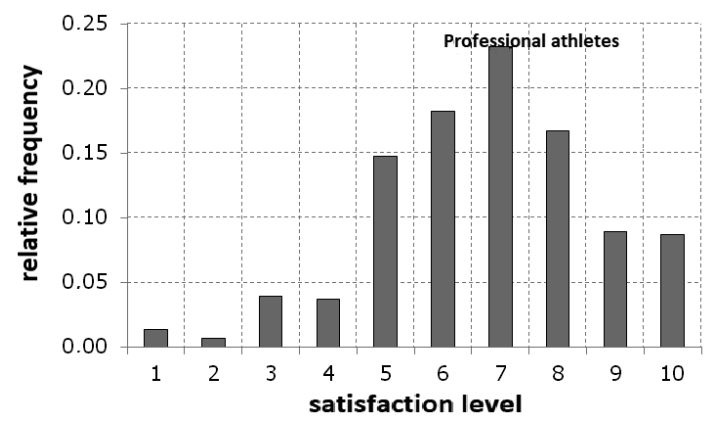

Figure 2. The availability of sport and recreation facilities in the city in the opinion of service recipients (professional athletes)

Source: own study.

Table 2. Statistical characteristics of ratings regarding availability of sport and recreation facilities in the city in the opinion of service recipients

\begin{tabular}{lccccccc}
\hline \multicolumn{1}{c}{ Statistical measures } & $\overline{\mathrm{X}}$ & $\mathrm{S}$ & $\mathrm{SK}$ & $\mathrm{K}$ & $\mathrm{N}$ & $\begin{array}{c}\text { Test for equality } \\
\text { of means } \\
p\end{array}$ & $\begin{array}{c}\text { Test for equality } \\
\text { of variances } \\
p\end{array}$ \\
\hline Amateurs & 6.414 & 1.859 & -0.555 & 4.170 & 683 & 0.3041 & 0.0001 \\
Professionals & 6.538 & 2.211 & -0.839 & 4.046 & 476 & & \\
\hline
\end{tabular}

Source: own study.

Figures 4-8 and Table 3 present the level of satisfaction with the availability of sport and recreation facilities in the place of residence, i.e. the city district. The study included the administrative division of the city into 5 districts: Grunwald, Jeżyce, Nowe Miasto, Stare Miasto, and Wilda.

The comparison of five districts in Poznan, in the opinion of the surveyed recipients, clearly indicates Nowe Miasto as the district that offers the greatest opportunities to use sport and recreation facilities. $27.6 \%$ of surveyed service recipients indicated this district. Moreover, the applied ANOVA test (test for equality of means and equality of variances) proved the statistical significance of differences in the assessment of particular districts (Table 3). In this way, service recipients expressed their opinions about the sport and recreation offer presented by facilities located in their place of residence (district) (Figure 3).

Figures 4-8 illustrate the level of satisfaction with the availability of sport and recreation facilities in individual districts of the city of Poznań, rated by the respondents. The characteristics of satisfaction levels regarding availability of sport and recreation facilities in individual districts in Poznań indicate Nowe Miasto and Stare Miasto as the highest scored districts. According to the service recipients, the differences between evaluated districts in Poznań, which were presented in table 3 , proved to be statistically important $(\mathrm{p}<0.01)$. Although the values are close to each other, ANOVA test firmly contradicts the hypothesis of equal averages. This probably results from 


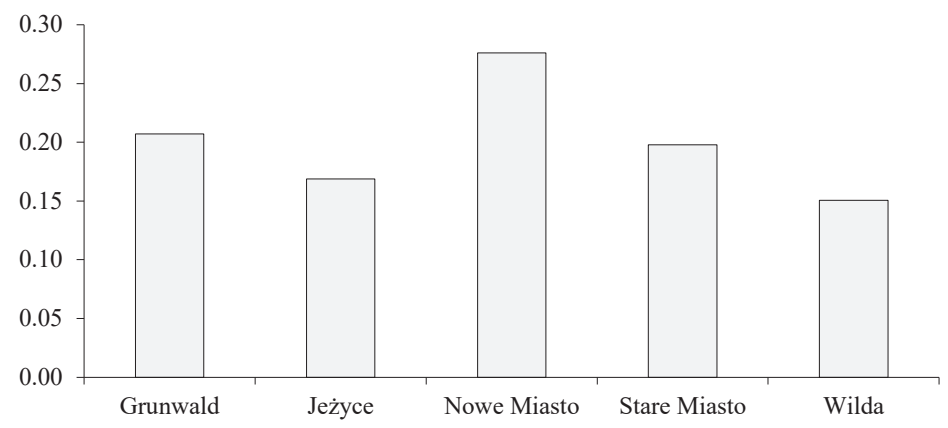

Figure 3. The distribution of possibility to use sport and recreation facilities by service recipients in their place of residence (district)

Source: own study.

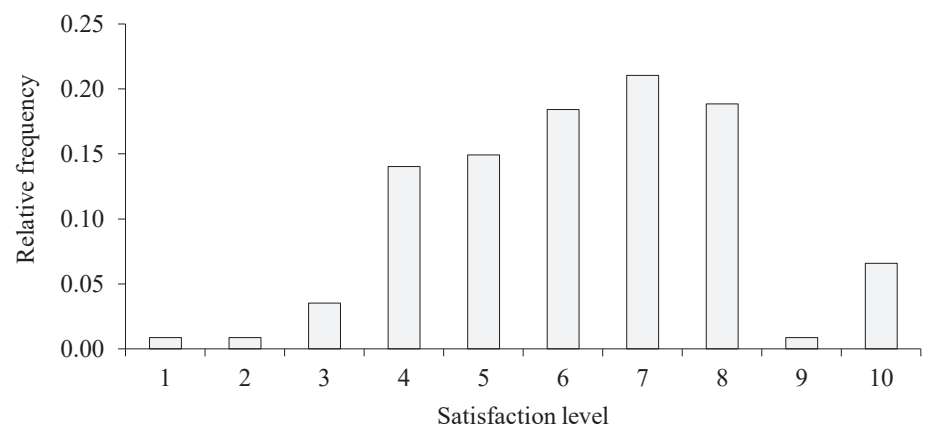

Figure 4. The level of satisfaction with the availability of sport and recreation facilities in the Grunwald district Source: own study.

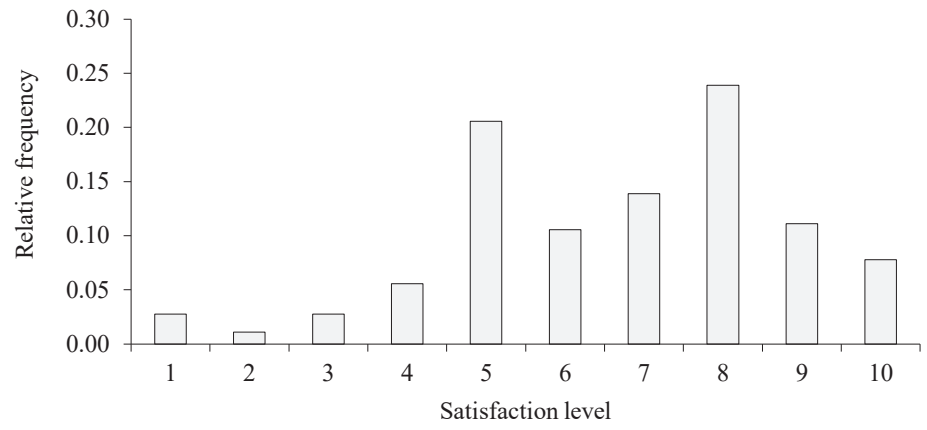

Figure 5. The level of satisfaction with the availability of sport and recreation facilities in the Jeżyce district Source: own study. 


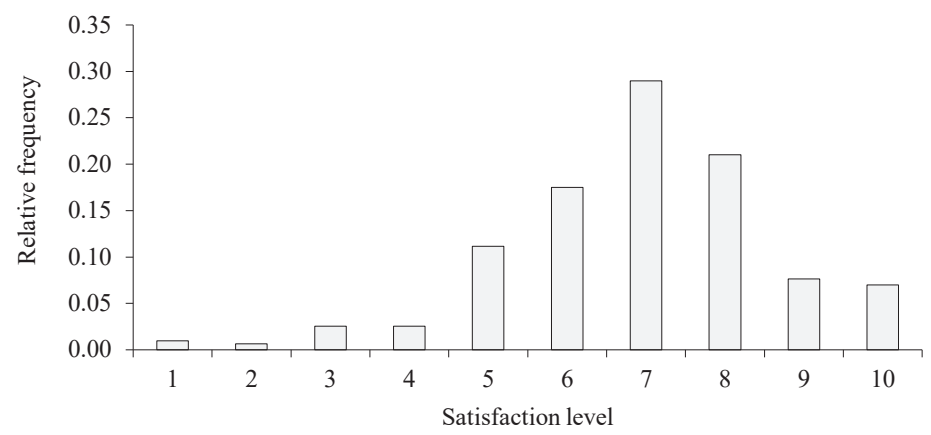

Figure 6 . The level of satisfaction with the availability of sport and recreation facilities in the Nowe Miasto district Source: own study.

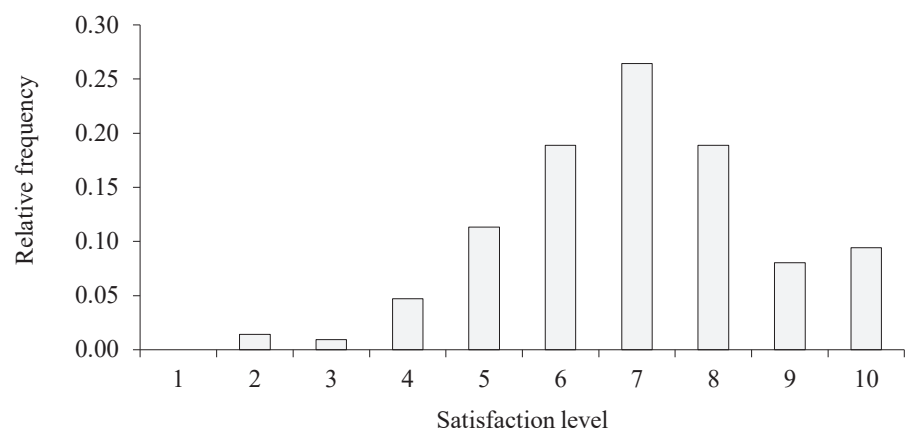

Figure 7. The level of satisfaction with the availability of sport and recreation facilities in the Stare Miasto district Source: own study.

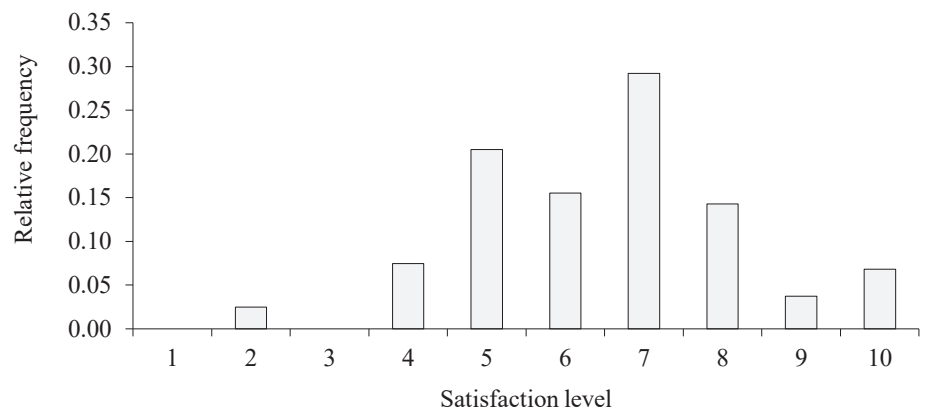

Figure 8. The level of satisfaction with the availability of sport and recreation facilities in the Wilda district Source: own study. 
differences in the distribution observed for Grunwald and Jeżyce. Nevertheless, negative values of skewness coefficient for every surveyed district show that there is a tendency to award points higher than the average. Therefore, it can be concluded that the residents of the city of Poznan are mostly satisfied with the possibility of access to sport and recreation facilities located in the city of Poznań. Thus, it was confirmed that the current state of sports and recreation infrastructure makes it possible for the city residents to actively spend time.

Table 3. The characteristics of satisfaction levels regarding availability of sport and recreation facilities in individual districts in Poznań according to service recipients

\begin{tabular}{lccccccc}
\hline \multicolumn{1}{c}{ District } & $\overline{\mathrm{X}}$ & $\mathrm{S}$ & $\mathrm{SK}$ & $\mathrm{K}$ & $\mathrm{N}$ & $\begin{array}{c}\text { Test for equality } \\
\text { of means } \\
p\end{array}$ & $\begin{array}{c}\text { Test for equality } \\
\text { of variances } \\
p\end{array}$ \\
\hline Grunwald & 5.735 & 2.486 & -0.734 & 3.319 & 249 & & \\
Jeżyce & 5.921 & 2.907 & -0.761 & 2.698 & 203 & & 0.002 \\
Nowe Miasto & $\mathbf{6 . 5 3 3}$ & 2.281 & -1.233 & 4.766 & 332 & 0.000 & \\
Stare Miasto & $\mathbf{6 . 2 0 6}$ & 2.713 & -1.044 & 3.566 & 238 & & \\
WILDA & 5.790 & 2.610 & -0.888 & 3.393 & 181 & & \\
\hline
\end{tabular}

Source: own study.

\section{Discussion}

In the modern world, sport, tourism and recreation constitute an important civilizational, cultural and economic value. Thanks to their specificity, they are an important factor in shaping health, developing habits and pro-health behaviours, as well as they constitute a very desirable form of spending free time. Therefore, the State has a strong interest in the development and popularization of sport. The increase in the level of physical activity of the society can be obtained mainly through activities aimed at increasing the accessibility of sport, as well as the development of a habit of constant striving in order to maintain a certain level of fitness (the Ministry of Sport, 2007). Insufficient access to sport and physical activity constitutes an important constraint to the physical activity of Polish people. By removing this obstacle, the effectiveness of programmes promoting physical activity and healthy lifestyle may be increased (Sieńko-Awierianów et al., 2015).

All citizens are guaranteed common access to physical culture goods by the Constitution of the Republic of Poland (Article 68 (5)). The obligation to ensure real participation in the use of these goods is imposed on both the government and local government. The responsibilities of local authorities in this respect are defined in, first and foremost, the acts on local governments and the Act on Sport of 2010, under which ensuring the conditions for the development of sport is the task of local government units (Śniadek, 2011).

Sport, tourism and recreation are an important area of activity of the authorities in Poznań, who each year devote more than $6 \%$ of the city's budget to physical culture. Thanks to that, Poznań achieves a level equal to the EU average in this respect (Bąk, 2010). Expenditure on physical activity is the highest in the country, amounting to $12.3 \%$ of the city's budget. Expenditure is channelled 
towards investments in recreation and sport infrastructure, improvement of conditions for practicing various disciplines or organization of important sport events. One of the strategic goals presented in the City Council Resolution on the Development Strategy for the city of Poznan until the year 2030, implemented on 11 May 2010, is increasing the importance of the city as a centre of sport (Rogala, 2011). From among many tasks envisaged in the programs, particular emphasis was put on the development of sport and recreation infrastructure, revitalization of the urban space for the needs of physical recreation, activity in effort to organize international sport events and creating the image of Poznań as an international sports centre (Śniadek, 2011).

When evaluating the level of satisfaction with availability of sports and recreational services in Poznań, an attempt was made to examine the response to marketing actions undertaken by the City Government of Poznań in the scope of sports and recreational services. However, it must be clearly emphasized that the proper determination of the level of these services significantly depends on promotion, particularly on the accuracy of the selection of promotional instruments. In a situation when physical activity is performed only thanks to the available sport and recreation facilities, sports and recreational services are a condition for undertaking this activity.

Consumption patterns in the sphere of recreational and sports services are in part caused by the implemented economic and social policy, as well as shaped to a large extent by a number of other conditions (factors). Daszkowska divides them into objective and quasi-subjective. Moreover, she distinguishes overall economic factors in these groups on both the demand and the supply side, as well as demographical and sociological ones (Daszkowska, Senyszyn, 1994). The studied availability of sports and recreational services is presented in the group of stimulating, supply factors objectively shaping the consumption of recreational and sports services. The literature on the subject clearly states that the consumption of sports and recreational services in Poland depends on two main factors: those in the sphere of needs and motivations, and broadly understood accessibility.

\section{Conclusions}

The summary of the analysis of the service recipients' opinions, divided into amateur and professional athletes, regarding the attractiveness of sport and recreation facilities and the possibility to use them, led to many interesting conclusions. Both surveyed groups highly evaluated the provision of equipment in sport and recreation facilities, the availability of services and the range of sports and recreation activities. Thus, it was confirmed that the current state of sport and recreation infrastructure makes it possible for the city residents to actively spend time. Therefore, the sport and recreation offer provided by the city to residents and tourists should be varied and properly adapted to the requirements, type and nature of the recipients' expectations.

\section{Referencess}

Basińska-Zych, A., Bosiacki, S. (2011). Polityka lokalna w stymulowaniu rozwoju rekreacji ruchowej w wybranych państwach Unii Europejskiej. Zeszyty Naukowe Uniwersytetu Szczecińskiego, 690. Ekonomiczne Problemy Ustug, 79, 349-369. 
Bąk, E. (2010). Rola sportu w strategii rozwoju miasta Poznania, czyli dlaczego "Poznań stawia na sport”. In: B. Sojkina (ed.), Sport w Poznaniu i Wielkopolsce. Poznań: Wydawnictwo Uniwersytetu Ekonomicznego w Poznaniu.

Daszkowska, M., Senyszyn, J. (1994). Elementy teorii konsumpcji. Gdańsk: Wydawnictwo Uniwersytetu Gdańskiego.

Data of Poznań City Council (2012).

Kogut-Jaworska, M. (2011). Wdrażanie i monitorowanie strategii rozwoju sportu i rekreacji w samorządach lokalnych. Zeszyty Naukowe Uniwersytetu Szczecińskiego, 690. Ekonomiczne Problemy Ustug, 79, 375-381.

Rogala, A. (2011). Rola sportu w promocji miast. Zeszyty Naukowe Uniwersytetu Szczecińskiego, 690. Ekonomiczne Problemy Ustug, 79, 217-227.

Sieńko-Awierianów, E., Chudecka, M., Eider, J. (2015). Wpływ doświadczenia sportowego rodziców na uczestnictwo w zajęciach sportowych dzieci. Marketing i Rynek, 11, 275-280.

Śniadek, J. (2011). Rola sportu w promocji miast. Zeszyty Naukowe Uniwersytetu Szczecińskiego, 690. Ekonomiczne Problemy Ustug, 79, 217-227.

The Ministry of Sport (2007). Strategia Rozwoju Sportu w Polsce do 2015 roku. Retrieved from: http://www.msport.gov. $\mathrm{pl} /$ sport (10.04.2015).

\section{OCENA MOŻLIWOŚCI KORZYSTANIA \\ Z OBIEKTÓW SPORTOWO-REKREACYJNYCH W POZNANIU}

\author{
SŁOWA KLUCZOWE \\ STRESZCZENIE
}

infrastruktura sportowo-rekreacyjna, usługi sportowo-rekreacyjne, badania ankietowe

Ranga oraz znaczenie sportu, turystyki i rekreacji w rozwoju miast i regionów świata jest już uznana i niepodważalna. Współczesne miasto w swoich przestrzeniach publicznych posiada różnorodne miejsca aktywności społecznej, w których przestrzeń sportowo-rekreacyjna stanowi specyficzną i atrakcyjną ofertę. Sport to ważny obszar aktywności władz w Poznaniu, gdzie wydatki na kulturę fizyczną należą do najwyższych w kraju i dorównują pod tym względem średniej unijnej.

Celem pracy była ocena możliwości korzystania z obiektów sportowo-rekreacyjnych na terenie miasta Poznania, oraz z oferowanych w nich usług sportowo-rekreacyjnych. Dla realizacji celów pracy przeprowadzono badania ankietowe wśród 39 usługodawców i 1159 usługobiorców w wybranych obiektach sportowo-rekreacyjnych w Poznaniu. Analiza opinii usługobiorców, z podziałem na amatorsko i wyczynowo uprawiających sport, wykazała, że obie grupy badanych wysoko oceniły stopień wyposażenia w sprzęt obiekty sportowo-rekreacyjne oraz dostępność usług i ofertę zajęć sportowo-rekreacyjnych. Zastosowany test istotności wariancji badanych zmiennych między grupami pozwolił wyodrębnić istotne różnice w rozkładzie badanych cech, odzwierciedlając różnorodność opinii w badanych grupach. Różnice te wynikają z rożnych oczekiwań osób wyczynowo uprawiających sport i amatorsko korzystających z obiektów sportowo-rekreacyjnych wobec efektywności polityki Urzędu Miasta Poznania. 